\title{
Pichia garciniae sp. nov., isolated from a rotten mangosteen fruit (Garcinia mangostana L., Clusiaceae)
}

\author{
Bhaskar Bhadra, Zareena Begum and Sisinthy Shivaji \\ Centre for Cellular and Molecular Biology, Uppal Road, Hyderabad 500007, India
}

Correspondence

Sisinthy Shivaji

shivas@ccmb.res.in
Yeasts of the genera Rhodotorula, Cryptococcus, Sporobolomyces, Saccharomyces, Candida and Pichia, amongst others, have been isolated from fresh and rotten fruits (Fleet, 2003; Rao et al., 2007; Bhadra et al., 2007; Slavikova et al., 2007). These fruit-associated yeasts produce extracellular enzymes such as lipases, cutinases and pectinases and thus hasten the spoilage of fruits during storage and transportation (Fleet, 2003). A number of novel yeast strains have been isolated from both healthy and rotten fruits (Péter et al., 2005; Tournas \& Katsoudas, 2005; Rao et al., 2007; Bhadra et al., 2007). During the course of a study to identify yeasts associated with a decaying mangosteen fruit (Garcinia mangostana L., Clusiaceae), a number of yeast strains were isolated. Detailed polyphasic taxonomic analysis indicated that the

The GenBank/EMBL/DDBJ accession numbers for the 18S rRNA gene (partial)-ITS1-5.8S rRNA gene-ITS2-26S rRNA gene (partial) sequences of strains $\mathrm{YS}_{110^{\top}}$ and $\mathrm{YS} 111$ are respectively AM882679 and AM905031, and those of the D1/D2 domains of the 26S rRNA genes of strains YS119, YS118 and YS117 are AM882676AM882678, respectively.

RAPD profiles from 12 novel yeast isolates are available as supplementary material with the online version of this paper. strains are representatives of the genus Pichia. Based on biochemical characteristics and the sequence of the D1/D2 domain of the 26S rRNA gene and the ITS1-5.8S rRNA gene-ITS2 region, strains YS110 ${ }^{\mathrm{T}}$ and YS111 represent a novel species of the genus Pichia.

Mangosteen fruits (about $1 \mathrm{~kg}$ ) were purchased in May 2007 from a market in the city of Bangkok, Thailand, and transported to Hyderabad, Andhra Pradesh, India. Most of the fruits remained unspoiled for about a week after one of them showed visible signs of rotting. A small piece from the rotten fruit (approx. $1 \mathrm{~g}$ ) was sliced using a sterile scalpel blade and suspended in $2 \mathrm{ml}$ sterile distilled water by vigorous vortexing. The resulting suspension $(100 \mu \mathrm{l})$ was then plated on YM agar plates $\left(1^{-1}: 5 \mathrm{~g}\right.$ peptone, $3 \mathrm{~g}$ yeast extract, $3 \mathrm{~g}$ malt extract, $10 \mathrm{~g}$ glucose and $15 \mathrm{~g}$ agar) supplemented with $50 \mu \mathrm{g}$ chloramphenicol ml $\mathrm{ml}^{-1}$ and the plates were incubated at $28{ }^{\circ} \mathrm{C}$ for $48 \mathrm{~h}$. The abundance of yeasts in the decaying mangosteen fruit was $2.0-2.2 \times 10^{2}$ c.f.u. $\mathrm{g}^{-1}$. A total of 32 yeast colonies appeared on YMchloramphenicol plates, which could be grouped into four morphotypes based on the colour and shape of the colonies. Three representatives of each colony morphotype were purified by repeated streaking on YM agar plates 
without the antibiotic and genomic DNA of the 12 isolates was extracted (Bhadra et al., 2007) and purified (Makimura et al., 1994). Following RAPD analysis using $(\mathrm{GTG})_{5}$ as a primer (Bhadra et al., 2007), the 12 isolates could also be classified into four groups, G-I, G-II, G-III and G-IV, based on the banding pattern of the PCR products when resolved on a $1 \%$ agarose gel (Supplementary Fig. S1, available in IJSEM Online). One or two representatives from each group, YS110 ${ }^{\mathrm{T}}$ and YS111 from G-I, YS117 from G-II, YS118 from G-III and YS119 from G-IV, were then subjected to detailed phylogenetic analysis.

For routine subculturing and maintenance, the strains were grown on/in YM agar/broth at $28{ }^{\circ} \mathrm{C}$. Morphological, physiological and biochemical properties were determined as described by Yarrow (1998). All assimilation tests were performed twice and results were scored after both 1 and 3 weeks. An Axioplan microscope (Zeiss) was used to visualize the morphology of the vegetative cells and ascospores. Strains were grown on potato-dextrose-rose bengal agar (M938; HiMEDIA) $\left(1^{-1}: 200\right.$ g potato infusion, $20 \mathrm{~g}$ glucose, $0.008 \mathrm{~g}$ rose bengal, $0.05 \mathrm{~g}$ chloramphenicol and $15 \mathrm{~g}$ agar) and Gorodkowa agar $\left(\mathrm{l}^{-1}: 1 \mathrm{~g}\right.$ glucose, $10 \mathrm{~g}$ peptone, $5 \mathrm{~g} \mathrm{NaCl}$ and $18 \mathrm{~g}$ agar) and visualized after 3, 5, 7, 10 and 12 days for ascospore formation using a phasecontrast microscope under a $\times 100$ oil-immersion objective. Candida albicans JCM $1542^{\mathrm{T}}$, P. membranifaciens NRRL Y-2026 ${ }^{\mathrm{T}}$ and $P$. manshurica NRRL Y $-17978^{\mathrm{T}}$ were used as reference strains for phenotypic studies.

Quinones were extracted and purified from cells grown in $250 \mathrm{ml}$ YM broth for 3-5 days according to Yamada et al. (1989). The dark band of Co-Q observed under UV light was scraped and extracted with $2 \mathrm{ml}$ acetone and identified using reversed-phase HPTLC (Thanh et al., 2003) using Co-Q standards (Sigma-Aldrich). Saccharomyces cerevisiae NRRL Y-12632 ${ }^{\mathrm{T}}$, Pichia fermentans NRRL Y-1619 ${ }^{\mathrm{T}}, P$. membranifaciens NRRL Y-2026 ${ }^{\mathrm{T}}$, Debaryomyces hansenii NRRL Y-17914 ${ }^{\mathrm{T}}$ and Schizosaccharomyces pombe NRRL Y$12796^{\mathrm{T}}$ were used as reference strains for Co-Q analysis. The $\mathrm{G}+\mathrm{C}$ content of the DNA was determined from melting point $\left(T_{\mathrm{m}}\right)$ curves (Sly et al., 1986) obtained using a Lambda 2 UV-visible spectrophotometer (Perkin Elmer) equipped with Templab 2.0 software package (Perkin Elmer). DNA-DNA hybridization was performed using a DIG DNA labelling and detection kit (Roche Diagnostics) according to Bhadra et al. (2005).

The internal transcribed spacer (ITS) region including the 5.8S rRNA gene (ITS1-5.8S rRNA gene-ITS2) and the D1/

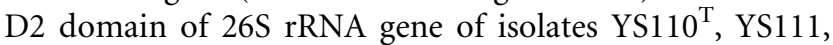
YS117, YS118 and YS119 were amplified using the primers ITS1 and NL4 and the amplicon was sequenced using the primers NL1, NL2A, NL3A, ITS3 and ITS4 (Lin et al., 1995; Kurtzman \& Robnett, 1998). Details of amplification and sequencing protocols are given elsewhere (Bhadra et al., 2007). Sequences were corrected manually and aligned using CLUSTAL_X (Thompson et al., 1997). Pairwise alignment studies were done using the ExPASy
Bioinformatics online software tools (http://www.expasy.ch/tools/sim-prot.html). Phylogenetic analyses were conducted using MEGA 3.1 (Kumar et al., 2004) according to Rao et al. (2007). Bootstrap analysis (Felsenstein, 1985) was performed for 1000 replications. Reference sequences were retrieved from GenBank under the accession numbers indicated in the tree (Fig. 1).

Pairwise alignment analysis of the nucleotide sequences of the D1/D2 domains of the 26S rRNA genes of strains YS117, YS118 and YS119 showed $100 \%$ similarity to those of Pichia anomala NRRL Y-366 ${ }^{\mathrm{T}}$ (GenBank accession no. U74592; not shown in Fig. 1), P. fermentans NRRL Y-1619 ${ }^{\mathrm{T}}$ and $P$. manshurica NRRL Y-17349 (the type strain of Pichia galeiformis), respectively. In the neighbour-joining phylogenetic tree constructed using D1/D2 sequences, YS117 grouped with $P$. anomala NRRL Y-366 ${ }^{\mathrm{T}}$ (data not shown), whereas YS118 and YS119 grouped with $P$. fermentans NRRL Y $-1619^{\mathrm{T}}$ and P. manshurica IFO $10726^{\mathrm{T}}$, respectively (Fig. 1). These strains also showed similar biochemical characteristics to their nearest phylogenetic relatives and produced ascospores after 5 days of incubation on potatodextrose-rose bengal agar plates (not shown). Therefore, strains YS117, YS118 and YS119 are assumed to be strains of $P$. anomala, $P$. manshurica and $P$. fermentans, respectively.

The nucleotide sequences of the D1/D2 domain of the 26S rRNA gene and the ITS1-5.8S-ITS2 region of representative strains of G-I, YS110 ${ }^{\mathrm{T}}$ and YS111, were almost identical (99.9\% similarity). BLAST analysis of the nucleotide sequence of the D1/D2 domain of $\mathrm{YS}_{110^{\mathrm{T}}}$ indicated that the nearest phylogenetic neighbours are P. membranifaciens and P. manshurica. Strain YS110 ${ }^{\mathrm{T}}$ showed $97 \%$ similarity with $P$. manshurica IFO $10726^{\mathrm{T}}, 96.3 \%$ similarity with $P$. membranifaciens NRRL Y-2026 ${ }^{\mathrm{T}}, 96.1 \%$ similarity with Pichia deserticola NRRL Y- $12918^{\mathrm{T}}$ and $96 \%$ similarity with Candida ethanolica NRRL Y-12615 ${ }^{\mathrm{T}}$. The phylogenetic tree constructed using the neighbour-joining method based on D1/D2 sequences further strengthens the conclusion that $\mathrm{YS} 110^{\mathrm{T}}$ is most closely related to $P$. membranifaciens, with a bootstrap support of $99 \%$ (Fig. 1). The nucleotide sequence of the ITS1-5.8S rRNA gene-ITS2 region of strain $\mathrm{YS}_{110^{\mathrm{T}}}$ shows $85.1 \%$ similarity to that of $P$. membranifaciens CBS 209 (GenBank accession no. DQ104714) and $81.4 \%$ similarity to that of P. manshurica IFO $10726^{\mathrm{T}}$ (AB054036). Based on rRNA gene sequencing and electrophoretic karyotyping, Wu et al. (2006) reported that strains identified as $P$. membranifaciens could show 5$13 \%$ variation in their ITS1-5.8S rRNA gene-ITS2 region nucleotide sequence. Therefore, a DNA-DNA relatedness study was conducted between strains $\mathrm{YS} 110^{\mathrm{T}}$ and YS111, $P$. membranifaciens NRRL Y-2026 ${ }^{\mathrm{T}}$ and $P$. manshurica NRRL Y-27978 ${ }^{\mathrm{T}}$. Strains $\mathrm{YS}_{110^{\mathrm{T}}}$ and YS111 showed $92 \%$ DNADNA relatedness with each other and both strains showed 52-57\% DNA-DNA relatedness with P. membranifaciens NRRL Y-2026 ${ }^{\mathrm{T}}$ and P. manshurica NRRL Y-27978 ${ }^{\mathrm{T}}$.

Previous studies have shown that strains with $>1 \%$ substitution in the D1/D2 domain sequence usually 


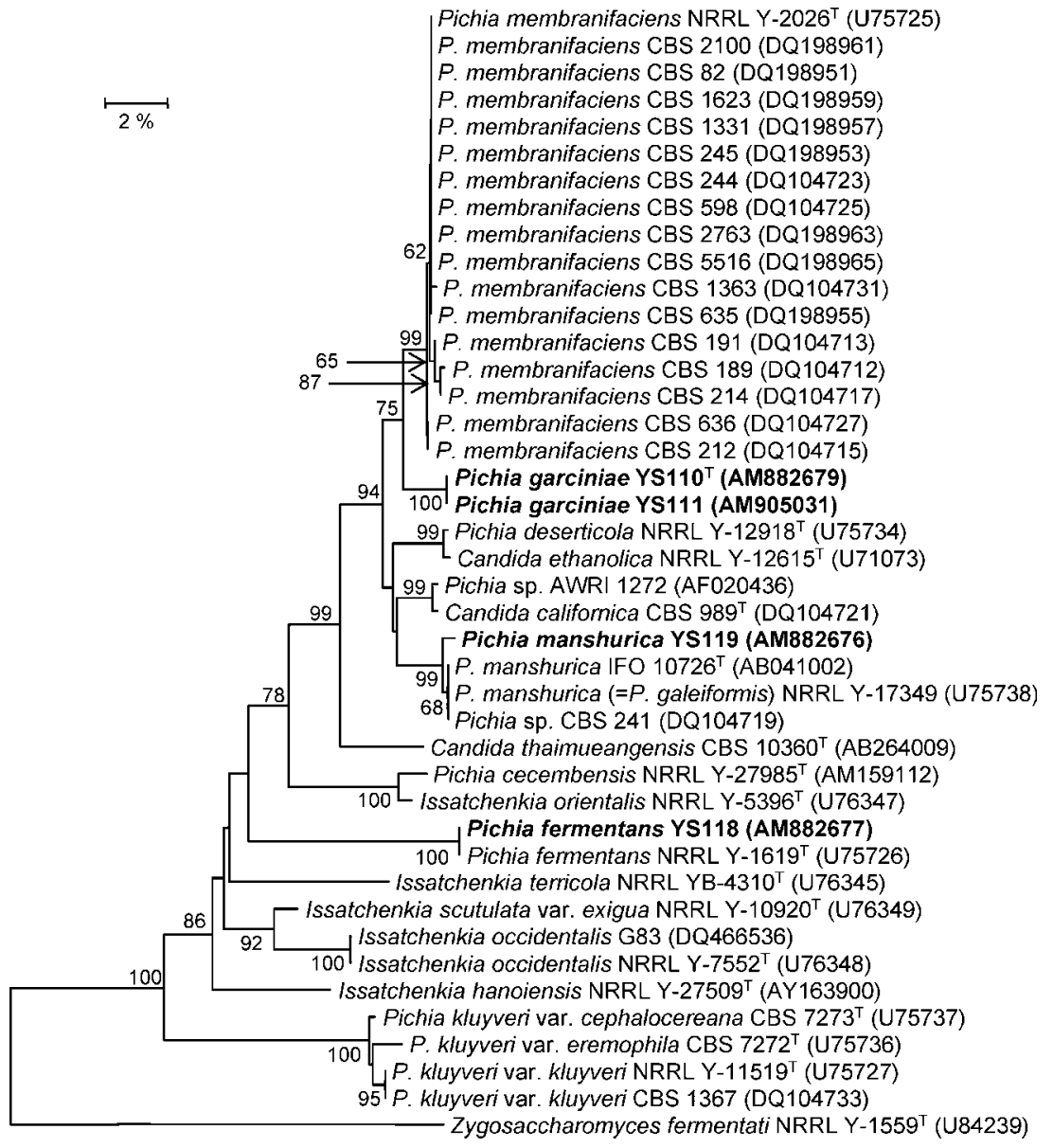

Fig. 1. Phylogenetic tree drawn using the neighbour-joining method with Kimura's twoparameter model based on the D1/D2 domain sequence of the 26S rRNA gene, depicting the relationships of Pichia garciniae sp. nov. strains $Y_{S 110^{\top}}$ and $Y S 111$ with related species of the genera Pichia, Candida and Issatchenkia. Zygosaccharomyces fermentati NRRL $\mathrm{Y}-1559^{\top}$ was used as an outgroup. Bootstrap values calculated as percentages from 1000 replications are indicated at branch nodes. Sequences that were obtained in this study are indicated in bold. Bar, 2 substitutions per 100 nucleotide positions. represent separate species (Kurtzman \& Robnett, 1997, 1998; Lu et al., 2004; Suh \& Blackwell, 2004). Strains $\mathrm{YS}_{110^{\mathrm{T}}}$ and YS111 differ by $3-3.7 \%$ in their D1/D2 sequence and $14.9-18.6 \%$ in their ITS1-5.8S rRNA geneITS2 region sequence from the type strains of $P$. membranifaciens and $P$. manshurica. The DNA-DNA relatedness of $\mathrm{YS} 110^{\mathrm{T}}$ and YS111 with the type strains of P. membranifaciens and $P$. manshurica was $<70 \%$. Therefore, based on phylogenetic analysis and DNADNA relatedness studies, strains $\mathrm{YS}_{110^{\mathrm{T}}}$ and YS111 should be regarded as strains of a novel species of the genus Pichia. Strains $\mathrm{YS}_{110^{\mathrm{T}}}$ and YS111 do not differ significantly in their phenotypic properties from strains of P. membranifaciens as reported by Barnett et al. (2000) but, when $\mathrm{YS}_{110^{\mathrm{T}}}$ and YS111 were compared directly in this study with the type strain of P. membranifaciens, NRRL Y-2026 ${ }^{\mathrm{T}}$, differences were clearly visible (Table 1). The strains produce two to four ascospores after 3-5 days of incubation on potato-dextrose-rose bengal agar and Gorodkowa agar (Fig. 2). Thus, based on phenotypic differences, phylogenetic analysis and DNA-DNA relatedness studies, strains $\mathrm{YS}_{110^{\mathrm{T}}}$ and YS111 represent a novel species of Pichia, for which the name Pichia garciniae sp. nov. is proposed.

\section{Latin diagnosis of Pichia garciniae Bhadra et Shivaji sp. nov.}

In medio agaro YM post dies 3 ad $28{ }^{\circ} \mathrm{C}$, cellulae vegetativae globosae aut oblongae $(4-7 \times 3.5-4 \mu \mathrm{m})$, cellulae singulae, binae et aggregatae. Per gemmationem multipolarem reproducentes. Post 1 mensem ad $28{ }^{\circ} \mathrm{C}$ pellicula et sedimentum formantur. In agaro YM post dies 15 ad $28{ }^{\circ} \mathrm{C}$, colonia butyrosa, glabra. Ascosporae 2-4 per ascum. D-Glucosum nonfermentatur. Assimilantur D-glucosum, D-glucosaminum (infirme), glycerolum, xylitolum et succinatum; non-assimilantur D-galactosum, L-sorbosum, D-ribosum, D-xylosum, Larabinosum, D-arabinosum, L-rhamnosum, sucrosum, maltosum, cellobiosum, salicinum, melibiosum, lactosum, raffinosum, melezitosum, amylosum, erythritolum, ribitolum, myo-inositolum, D-gluconatum, D-glucuronatum, citratum, propane-1,2diolum et butane-2,3-diolum. Assimilantur ethylaminum, Llysinum, cadaverinum et glucosaminum; non-assimilantur nitratum, nitritum, creatininum et imidazolum. Crescit et medio $0.01 \%$ cycloheximido addito. Ureum non-hydrolysatur. Diazonium caeruleum B non-respondens. Ubiquinone majus Q7. G $+\mathrm{C}$ acidi deoxyribonucleati 48.5 mol\%. Typus $\mathrm{YS}_{110^{\mathrm{T}}}$ $\left(=\mathrm{NRRL} Y-48422^{\mathrm{T}}=\mathrm{CBS} 10758^{\mathrm{T}}\right)$, designat stirpem typicum. Isolata ex gut mangosteen fructu (Garcinia mangostana L., Clusiaceae), depositata in CBS, Hollandia. 
Table 1. Phenotypic characteristics of strains $\mathrm{YS} 110^{\top}$ and $\mathrm{YS} 111, P$. membranifaciens and $P$. manshurica

Data were obtained in this study unless indicated. All strains assimilate D-glucose but not D-galactose, L-sorbose, D-ribose, D-xylose, L-arabinose, Darabinose, L-rhamnose, sucrose, maltose, cellobiose, salicin, melibiose, lactose, raffinose, melezitose, starch, erythritol, ribitol, myo-inositol, Dgluconate, D-glucuronate, propane-1,2-diol or butane-2,3-diol as sole carbon sources. All strains assimilate ethylamine, L-lysine, cadaverine and glucosamine but not nitrate, nitrite, creatinine or imidazole as sole nitrogen sources. All strains are sensitive to $0.1 \%$ cycloheximide and do not grow in medium containing $1 \%(\mathrm{v} / \mathrm{v})$ methanol. None of the strains form starch-like compounds or hydrolyse urea and all strains give a negative diazonium blue B reaction. +, Positive; $\mathrm{w}$, weakly positive, D, variable; -, negative.

\begin{tabular}{|c|c|c|c|c|}
\hline \multirow[t]{2}{*}{ Property } & \multirow{2}{*}{$\begin{array}{c}\text { Strains } \mathrm{YS} 110^{\mathrm{T}} \text { and } \\
\text { YS111 }\end{array}$} & \multicolumn{2}{|c|}{ P. membranifaciens } & \multirow{2}{*}{$\begin{array}{c}\text { P. manshurica NRRL Y- } \\
27978^{\mathrm{T}}\end{array}$} \\
\hline & & NRRL Y-2026 ${ }^{\mathrm{T}}$ & Barnett et al. (2000) & \\
\hline Fermentation of D-glucose & - & $\mathrm{D}$ & $\mathrm{D},-$ & - \\
\hline \multicolumn{5}{|l|}{ Assimilation of: } \\
\hline D-Glucosamine & $\mathrm{W}$ & $\mathrm{W}$ &,+- & - \\
\hline Inulin & - & - & - & $\mathrm{w}$ \\
\hline Glycerol & + & + &,+- & - \\
\hline Xylitol & + & - &,+- & - \\
\hline Succinate & + & $\mathrm{D}$ &,+- & - \\
\hline Citrate & - & - &,+- & - \\
\hline \multicolumn{5}{|l|}{ Growth in: } \\
\hline Acetic acid (1\%) & - & - &,+- & - \\
\hline Cycloheximide $(0.01 \%)$ & + & - & $\mathrm{D},-$ & - \\
\hline D-Glucose $(50 \%)$ & - & $\mathrm{W}$ &,+- & - \\
\hline
\end{tabular}

\section{Description of Pichia garciniae Bhadra \& Shivaji sp. nov.}

Pichia garciniae (gar.ci'ni.ae. N.L. gen. fem. n. garciniae of Garcinia, a botanical genus name, referring to the isolation

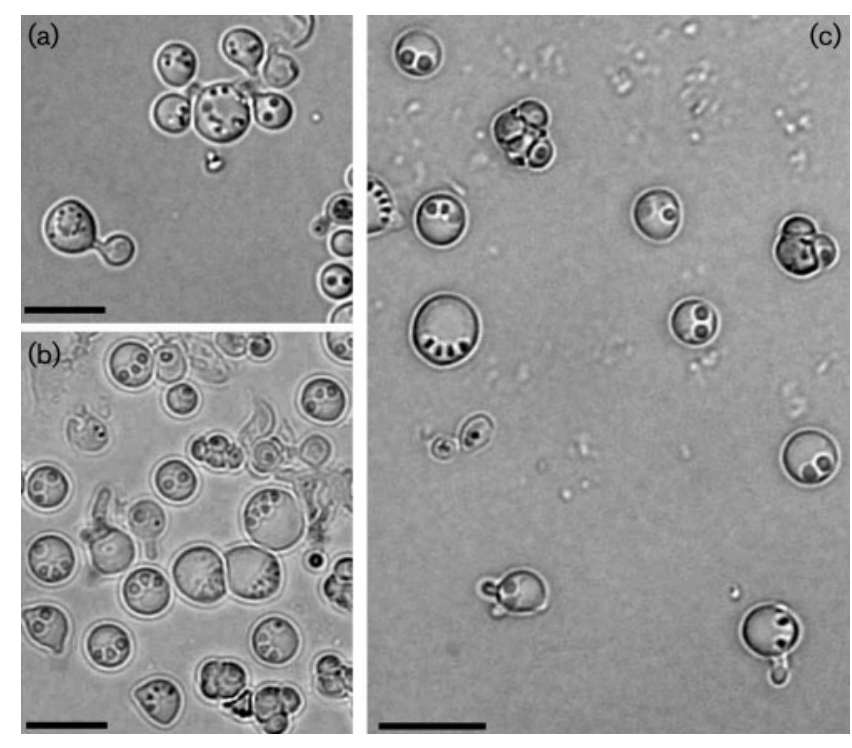

Fig. 2. Phase-contrast micrographs of Pichia garciniae sp. nov. YS110 ${ }^{\top}$ showing conjugating cells (a), automictic cells bearing protuberances and released ascospores $(b, c)$. Cells were grown at $28{ }^{\circ} \mathrm{C}$ for $3-5$ days on potato-dextrose-rose bengal agar. Bars, $6 \mu \mathrm{m}$. of the type strain from rotting fruit of mangosteen, Garcinia mangostana L.).

After 3 days on YM agar at $28{ }^{\circ} \mathrm{C}$, cells are spherical or ovoid $(4-7 \times 3.5-4 \mu \mathrm{m})$ and occur singly, in pairs or in groups (Fig. 2). Budding is multilateral. After 1 month at $28{ }^{\circ} \mathrm{C}$, sediment and pellicle formation is observed. On YM agar medium after 15 days at $28{ }^{\circ} \mathrm{C}$, the culture is butyrous, pale brownish in colour, smooth with a rough margin. Pseudohypha formation is not observed on YM agar or cornmeal agar plates after 10-21 days of incubation at $28{ }^{\circ} \mathrm{C}$. After $3-5$ days of incubation at $28{ }^{\circ} \mathrm{C}$ on Gorodkowa agar and potato-dextrose-rose bengal agar, conjugation is followed by formation of two to four hatshaped ascospores per cell. Asci deliquescent. Cells do not ferment D-glucose. Assimilates D-glucose, D-glucosamine (weakly), glycerol, xylitol and succinate but does not assimilate D-galactose, L-sorbose, D-ribose, D-xylose, L- or D-arabinose, L-rhamnose, sucrose, maltose, cellobiose, salicin, melibiose, lactose, raffinose, melezitose, starch, erythritol, ribitol, myo-inositol, D-gluconate, D-glucuronate, citrate, propane-1,2-diol or butane-2,3-diol as sole carbon sources. Assimilates ethylamine, L-lysine, cadaverine and glucosamine but does not assimilate nitrate, nitrite, creatinine or imidazole as sole nitrogen sources. Does not grow in vitamin-free media. Strains are sensitive to $0.1 \%$ cycloheximide and do not grow in medium containing $1 \%$ (v/v) acetic acid or methanol. Resistant to $0.01 \%$ cycloheximide and does not grow in $50 \%$ glucose. Does not form starch-like compounds and does not hydrolyse urea and the diazonium blue $\mathrm{B}$ reaction is negative. 
Coenzyme Q7 is the major ubiquinone. The $\mathrm{G}+\mathrm{C}$ content of the DNA of the type strain is $48.5 \mathrm{~mol} \%$.

The type strain is $\mathrm{YS} 110^{\mathrm{T}}\left(=\mathrm{NRRL} \mathrm{Y}-48422^{\mathrm{T}}=\mathrm{CBS}\right.$ $\left.10758^{\mathrm{T}}\right)$, isolated from a decaying mangosteen fruit (Garcinia mangostana L., Clusiaceae).

\section{Acknowledgements}

The yeast strains were isolated as part of a project funded by the Council of Scientific and Industrial Research, New Delhi, India, to S. S. to characterize methylotrophic yeasts from the environment. We are also thankful to Professor C. Kurtzman of the ARS Culture Collection, Peoria, IL, USA, for providing us with type strains. Our special thanks go to Professor M.-A. Lachance for helping us to select and improve the photomicrographs of ascospores.

\section{References}

Barnett, J. A., Payne, R. W. \& Yarrow, D. (2000). Yeasts: Characteristics and Identification, 3rd edn, pp. 540-541. Cambridge: Cambridge University Press.

Bhadra, B., Roy, P. \& Chakraborty, R. (2005). Serratia ureilytica sp. nov., a novel urea-utilizing species. Int J Syst Evol Microbiol 55, 2155 2158.

Bhadra, B., Rao, S. R., Kumar, N. N., Chaturvedi, P., Sarkar, P. K. \& Shivaji, S. (2007). Pichia cecembensis sp. nov. isolated from a papaya fruit (Carica papaya L., Caricaceae). FEMS Yeast Res 7, 579-584.

Felsenstein, J. (1985). Confidence limits on phylogenies: an approach using the bootstrap. Evolution 39, 783-791.

Fleet, H. G. (2003). Yeasts in fruits and fruit products. In Yeasts in Food, pp. 267-271. Edited by T. Boekhout \& V. Robert. Hamburg: Behr's Verlag.

Kumar, S., Tamura, K. \& Nei, M. (2004). MEGA3: integrated software for molecular evolutionary genetics analysis and sequence alignment. Brief Bioinform 5, 150-163.

Kurtzman, C. P. \& Robnett, C. J. (1997). Identification of clinically important ascomycetous yeasts based on nucleotide divergence in the $5^{\prime}$ end of the large-subunit (26S) ribosomal DNA gene. J Clin Microbiol 35, 1216-1223.

Kurtzman, C. P. \& Robnett, C. J. (1998). Identification and phylogeny of ascomycetous yeasts from analysis of nuclear large subunit (26S) ribosomal DNA partial sequences. Antonie van Leeuwenhoek 73, $331-371$.
Lin, D., Wu, L. C., Rinaldi, M. G. \& Lehmann, P. F. (1995). Three distinct genotypes within Candida parapsilosis from clinical sources. $J$ Clin Microbiol 33, 1815-1821.

Lu, H. Z., Jia, J. H., Wang, O. M. \& Bai, F. Y. (2004). Candida asparagi sp. nov., Candida diospyri sp. nov. and Candida qinlingensis sp. nov., novel anamorphic, ascomycetous yeast species. Int $J$ Syst Evol Microbiol 54, 1409-1414.

Makimura, K., Murayama, S. Y. \& Yamaguchi, H. (1994). Detection of a wide range of medically important fungi by the polymerase chain reaction. J Med Microbiol 40, 358-364.

Péter, G., Tornai-Lehoczki, J., Suzuki, M. \& Dlauchy, D. (2005). Metschnikowia viticola sp. nov., a new yeast species from grape. Antonie van Leeuwenhoek 87, 155-160.

Rao, R. S., Bhadra, B., Kumar, N. \& Shivaji, S. (2007). Candida hyderabadensis sp. nov., a novel ascomycetous yeast isolated from wine grapes. FEMS Yeast Res 7, 489-493.

Slavikova, E., Vadkertiova, R. \& Vranova, D. (2007). Yeast colonizing the leaf surface. J Basic Microbiol 47, 344-350.

Sly, L. I., Blackall, L. L., Kraat, P. C., Tian-Shen, T. \& Sangkhobol, V. (1986). The use of second derivative plots for the determination of mol\% guanine plus cytosine of DNA by the thermal denaturation method. J Microbiol Methods 5, 139-156.

Suh, S. O. \& Blackwell, M. (2004). Three new beetle-associated yeast species in the Pichia guilliermondii clade. FEMS Yeast Res 5, 87-95.

Thanh, V. N., Hai, D. A. \& Lachance, M.-A. (2003). Issatchenkia hanoiensis, a new yeast species isolated from frass of the litchi fruit borer Conopomorpha cramerella Snellen. FEMS Yeast Res 4, 113-117.

Thompson, J. D., Gibson, T. J., Plewniak, F., Jeanmougin, F. \& Higgins, D. G. (1997). The CLUSTAL_X windows interface: flexible strategies for multiple sequence alignment aided by quality analysis tools. Nucleic Acids Res 25, 4876-4882.

Tournas, V. H. \& Katsoudas, E. (2005). Mould and yeast flora in fresh berries, grapes and citrus fruits. Int J Food Microbiol 105, 11-17.

Wu, Z.-W., Robert, V. \& Bai, F.-Y. (2006). Genetic diversity of Pichia membranifaciens strains revealed from rRNA gene sequencing and electrophoretic karyotyping, and the proposal of Candida californica comb. nov. FEMS Yeast Res 6, 305-311.

Yamada, Y., Gugihara, K., van Eijk, G. W., Roeijamans, H. J. \& de Hoog, G. S. (1989). Coenzyme Q systems in ascomycetous black yeasts. Antonie van Leeuwenhoek 56, 349-356.

Yarrow, D. (1998). Methods for the isolation, maintenance and identification of yeasts. In The Yeasts, a Taxonomic Study, 4th edn, pp. 77-100. Edited by C. P. Kurtzman \& J. W. Fell. Amsterdam: Elsevier. 